\title{
Nilai Perusahaan pada Struktur Modal Optimal PT. Trans Marga Jateng dan PT. Jasamarga Surabaya Mojokerto Tahun 2020
}

\author{
Aruji Murtianto* \\ Program Studi Magister Manajemen, Sekolah Tinggi Manajemen PPM \\ Jl. Menteng Raya No.9, Kb. Sirih, Kec. Menteng, Kota Jakarta Pusat, Jakarta, Indonesia \\ aruji_ntok@yahoo.co.id \\ Muhammad Taufik Akbar \\ Program Studi Magister Manajemen, Sekolah Tinggi Manajemen PPM \\ Jl. Menteng Raya No.9, Kb. Sirih, Kec. Menteng, Kota Jakarta Pusat, Jakarta, Indonesia \\ mtaufikakbar@gmail.com

\section{Nora Sri Hendriyeni} \\ Program Studi Magister Manajemen, Sekolah Tinggi Manajemen PPM \\ Jl. Menteng Raya No.9, Kb. Sirih, Kec. Menteng, Kota Jakarta Pusat, Jakarta, Indonesia \\ nora.hendriyeni@gmail.com
}

Diterima: 09-02-2021

Disetujui: 16-06-2021

Dipublikasi: 30-06-2021

\begin{abstract}
ABSTRAK
Dalam rangka menjaga kemampuan perusahaan untuk memenuhi kewajibannya, PT. Jasa Marga (Persero) Tbk akan melakukan aksi strategi korporasi penguatan untuk struktur modal bagi Anak Perusahaan Jalan Tol (/APJT). APJT yang terpilih adalah PT. Trans Marga Jateng (/PT. TMJ, sebagai pengelola ruas jalan tol Semarang-Solo) dan PT. Jasamarga Surabaya Mojokerto (/PT. JSM, sebagai pengelola ruas jalan tol Surabaya-Mojokerto) karena dinilai telah mampu memenuhi kewajiban hutangnya (/solvent). Aksi strategi korporasi dilakukan dengan analisis yang terkait dengan penilaian kinerja perusahaan, struktur modal yang optimal dan juga melakukan perhitungan nilai. Untuk Penilaian kinerja perusahaan, analisis dilakukan terhadap rasio keuangan perusahaan. Dilihat dari perhitungan dan analisis rasio profitabilitas, rasio likuiditas dan rasio solvabilitas, hasil kinerja keuangan PT. TMJ dan PT. JSM selama periode 2015-2019 menunjukan kinerja yang cukup baik. Komposisi struktur modal untuk nilai yang optimal bagi PT. TMJ dan PT. JSM berkisar antara 60:40 sampai dengan 30:70 untuk komposisi utang dan ekuitasnya. Hasil perhitungan nilai perusahaan dengan metode valuasi Discounted Cash Flow (DCF) menunjukan hasil bahwa nilai perusahaan PT. TMJ, dengan komposisi struktur modal 60:40 adalah senilai IDR.25.862,- /lembar saham dan dengan komposisi modal 70:30 nilai saham PT. TMJ sebesar IDR.10.418 ,/lembar saham. Sedangkan untuk PT. JSM dengan komposisi struktur modal 60:40 adalah senilai IDR.2.709,/lembar saham dan dengan komposisi modal 70:30 nilai saham PT. JSM sebesar IDR.911,- /lembar saham.Dari hasil analisis tersebut, Manajemen perusahaan harus lebih memperhatikan biaya modal yang sangat berpengaruh dalam penentuan struktur modal yg optimal sehingga dengan memperhatikan struktur tersebut APJT dapat melakukan penurunan porsi debt dan meningkatkan porsi equity dengan beberapa strategi.
\end{abstract}

Kata Kunci:

Kinerja Perusahaan; Struktur Modal; Valuasi; Nilai Perusahaan.

\section{ABSTRACT}

In order to maintain the company's ability to fulfill its liabilities, PT. Jasa Marga (Persero) Tbk will takes a corporate action strategy to strengthen capital structure for the Toll Road Subsidiaries (/APJT). APJT selected are PT. Trans Marga Central Java (/PT. TMJ, is the operator of Semarang-Solo toll road) and PT. Jasamarga Surabaya Mojokerto (/PT. JSM, is the operator of Surabaya-Mojokerto toll road) because of its capability to 
fulfill their solvents. Corporate action strategy done by analyze related with company performance baluation, optimal capital structure analysis. For Company performance valuation, analyze is done with company's financial ratios. From the calculation and analysis of profitability ratios; liquidity ratios and solvency ratios, PT. TMJ and PT. JSM during year 2015-2019 showed fair good performance. The composition of the capital structure to obtain optimal value for PT. TMJ and PT. JSM are range from 60:40 to 30:70 for the composition of debt and equity. The results of the company valuation using Discounted Cash Flow (DCF) method show that the company value of PT. TMJ, with a capital structure composition of 60:40 worth IDR. 25,862,- /share and with a capital composition of 70:30 share value of PT. TMJ in the amount of IDR.10,418,- /share. As for PT. JSM with a capital structure composition of 60:40 is IDR. 2,709,- /share and with a capital composition of 70:30 the share value of PT. JSM is IDR. 911,- /share. From analyze result, Management should pay more attention in capital expense due it's effect in Optimizing Capital Structure, then from that Optimal Capital structure, APJT can reduce debt portion dan increasing uts equity portion through several strategy.

Keywords:

Company Performance Capital Structure; Valuation; Company Value 


\section{PENDAHULUAN}

Untuk mendukung program pemerintah yang menargetkan pembangunan jalan tol baru sepanjang $2.500 \mathrm{~km}$ hingga tahun 2024, Jasa Marga sebagai salah satu Badan Usaha Milik Negara (BUMN) yang bergerak dalam bidang industri jalan tol turut berperan aktif mewujudkan rencana strategis pemerintah tersebut dengan menjalankan peran sebagai investor dan operator jalan tol. Hal tersebut dibuktikan, sampai dengan akhir tahun 2019 Jasa Marga telah memiliki hak konsesi untuk $1.527 \mathrm{~km}$ jalan tol, dimana $1.161 \mathrm{~km}$ jalan tol yang dimiliki telah beroperasi.

Saat ini, pengoperasian dan investasi jalan tol Jasa Marga dikelola dengan 8 (delapan) cabang; 15 (lima belas) entitas anak dan 5 (lima) entitas ventura bersama. Dari $1.162 \mathrm{~km}$ jalan tol yang beroperasi, $715 \mathrm{~km}$ merupakan ruas-ruas tol baru yang dioperasikan oleh Jasa Marga melalui entitas anak dan entitas ventura bersama sejak tahun 2011. Dengan pertambahan panjang jalan tol yang dimiliki Jasa Marga, maka nilai investasi dalam bentuk hak pengusahaan konsesi jalan tol juga meningkat, dimana dalam kurun waktu 5 (lima) tahun nilai investasi jalan tol Jasa Marga meningkat sebesar Rp.53,6 Triliun atau naik sebesar 216\% dari tahun 2015 yang hanya sebesar Rp.24,8 Triliun menjadi sebesar Rp.78,6 Triliun pada akhir tahun 2019.

Namun demikian, kenaikan nilai investasi jalan tol tersebut juga diiringi dengan kenaikan liabilitas dikarenakan sumber pendanaan/pembiayaan yang digunakan untuk meningkatkan nilai investasi jalan tol selain berasal dari modal sendiri, mayoritas juga berasal dari liabilitas terutama utang perbankan. Sumber pendanaan investasi yang mayoritas bersumber dari utang menjadikan peningkatan kewajiban Jasa Marga untuk menyelesaikan utang-utangnya dalam kurun waktu 5 (lima) tahun terakhir yang apabila tidak dikelola dengan baik berpotensi mempengaruhi kinerja Jasa Marga dalam penyelesaian kewajibannya. kinerja Jasa Marga dalam penyelesaian kewajibannya dapat diukur dengan menggunakan pendekatan rasio solvabilitas yaitu rasio untuk mengukur kemampuan perusahaan dalam menyelesaikan kewajibannya, baik kewajiban jangka panjang maupun kewajiban jangka pendek dengan jaminan aktiva atau kekayaan perusahaan. Kemampuan perusahaan dalam menyelesaikan kewajibannya tersebut diukur dengan menghitung rasio-rasio solvabilitas seperti Debt Equity Ratio (DER), Debt Ratio dan Interest Coverage Ratio (ICR).

Selama kurun waktu 5 (lima) tahun terakhir rasio perbandingan antara liabilitas (debt) dan ekuitas (equity) DER mengalami kenaikan sebesar 216\% dimana pada tahun 2015 rasio DER Jasa Marga hanya sebesar 1,97 kali, namun di akhir tahun 2019 mencapai 3,27 kali. Hal ini menunjukkan bahwa jumlah utang/liabilitas Perusahaan di tahun 2019 adalah 3,27 kali dari jumlah ekuitas yang dimiliki Perusahaan meskipun masih dibawah kebijakan yang dipersyaratkan yaitu sebesar 5 (lima) kali. Dari debt ratio dapat diketahui bahwa pada tahun 2019 perbandingan posisi liabilities dan equity yang dimiliki oleh Jasa Marga adalah 77\% liabilities dan 23\% adalah equity. Kondisi tersebut telah melebihi kebijakan yang ditetapkan bahwa perbandingan antara liabilitas (debt) dan ekuitas (equity) adalah sebesar 70:30. Selain itu kemampuan profitabilitas perusahan untuk memenuhi kewajiban pembayaran bunga (interest coverage ratio/ICR) di tahun 2019 mengalami penurunan hanya sebesar 
2,96 kali dibandingkan tahun 2018 yang mencapai 3,27 kali. Kemampuan profitabilitas perusahaan untuk memenuhi kewajiban pembayaran bunga tersebut meskipun masih diatas target minimal yang ditetapkan yaitu sebesar 1,5 kali, namun perlu menjadi perhatian karena selama 5 tahun terakhir mengalami penurunan akibat kenaikan jumlah utang yang mengakibatkan kenaikan beban bunga/beban keuangan.

Sebagai upaya untuk menjaga kinerja perusahaan agar tetap mampu memenuhi kewajibannya, pada tahun 2020 manajemen Jasa Marga berencana untuk melakukan aksi korporasi melalui strategi penguatan struktur modal bagi Anak Perusahaan Jalan Tol (APJT) yang telah beroperasi dan yang telah mampu untuk memenuhi/membayar kewajibannya (solvent). Strategi penguatan struktur modal yang akan diterapkan kepada APJT tersebut disesuaikan dengan kondisi perusahaan dan kondisi pasar. Dari 18 (delapan belas) APJT yang telah beroperasi, 5 (lima) APJT dianggap telah mampu memenuhi kewajiban/hutangnya (solvent). Kelima APJT tersebut adalah PT. Trans Marga Jateng (TMJ); PT. Jasamarga Surabaya Mojokerto (JSM); PT. Jasamarga Gempol Pasuruan (JGP); PT. Jasamarga Bali Tol (JBT) dan PT. Jasamarga Kualanamu Tol (JKT). Penerapan strategi penguatan struktur modal dengan penerbitan obligasi akan diterapkan di PT. TMJ dan PT. JSM. Untuk strategi penerbitan step up coupon loan akan diterapkan di PT. JGP dan PT. JBT serta strategi pelunasan pokok pinjaman yang dipercepat akan diterapkan oleh PT. JKT yang memiliki kelebihan cash dari kegiatan operasionalnya.

Strategi penguatan struktur modal merupakan kebijakan korporasi yang bertujuan untuk meningkatkan nilai perusahaan. Agar strategi penguatan struktur modal dapat meningkatkan nilai perusahaan maka perlu menentukan kombinasi sumber pendanaan yang mampu membentuk struktur modal optimal sehingga dapat meningkatkan nilai perusahaan. Untuk itu perlu mengetahui komposisi struktur modal yang optimal bagi APJT yang sudah beroperasi dan sudah solvent agar dapat meningkatkan nilai perusahaan. Dari 5 (lima) APJT yang beroperasi dan yang telah mampu memenuhi kewajiban/hutangnya (solvent), akan dibahas komposisi struktur modal yang optimal untuk 2 (dua) APJT yang akan meningkatkan nilai perusahaannya. Kedua APJT tersebut adalah PT. TMJ sebagai pengelola ruas jalan tol Semarang-Solo dan PT. JSM sebagai pengelola ruas jalan tol SurabayaMojokerto yang rencana akan menerbitkan obligasi sebagai strategi perkuatan struktur modalnya. Berdasarkan latar belakang tersebut, maka rumusan masalah tesis ini adalah:

1. Bagaimanakah kinerja keuangan dari PT. Trans Marga Jateng dan PT. Jasamarga Surabaya Mojokerto?

2. Bagaimanakah komposisi struktur modal yang optimal bagi PT. Trans Marga Jateng dan PT. Jasamarga Surabaya Mojokerto?

Berapakah nilai (valuasi) dari PT. Trans Marga Jateng dan PT. Jasamarga Surabaya Mojokerto?

\section{Penilaian Kinerja Perusahaan}

Penilaian kinerja suatu perusahaan merupakan hasil dari kegiatan manajemen di setiap perusahaan. Parameter yang sering digunakan untuk menilai kinerja suatu perusahaan adalah dengan 
menggunakan informasi yang diambil dari laporan keuangan. Laporan keuangan perusahaan terdiri atas laporan laba rugi (profit and loss), laporan posisi keuangan (balance sheet statement), laporan arus kas dan Laporan Perubahan Struktur Modal. Untuk lebih mengetahui kinerja suatu perusahaan dapat dilakukan dengan menghitung rasio-rasio keuangan perusahaan.

Menurut Raharjaputra (2011:196), “Analisis rasio adalah membandingkan antara satu angka dengan angka lainnya yang memberikan suatu makna. Suatu keuntungan dengan menggunakan rasio adalah meringkas suatu data historis perusahaan sebagai bahan perbandingan". Subramanyam dan Wild (2012:42) menambahkan, “Analisis rasio dapat mengungkapkan hubungan penting dan menjadi dasar perbandingan dalam menemukan kondisi dan tren yang sulit untuk dideteksi dengan mempelajari masing-masing komponen yang membentuk rasio". Adapun rasio-rasio yang digunakan untuk mengukur kinerja suatu perusahaan adalah sebagai berikut:

\section{Rasio Profitabilitas}

Menurut Prihadi (2019) laba menjadi salah satu tujuan utama didirikannya perusahaan. Oleh karena itu wajar apabila profitabilitas menjadi perhatian utama bagi para investor dan analis. Tingkat profitabilitas yang konsisten akan menjadi tolok ukur bagaimana perusahaan mampu bertahan dalam bisnisnya. Kashmir (2014) menjelaskan bahwa hasil pengukuran profitabilitas dapat dijadikan sebagai alat evaluasi kinerja manajemen selama ini, apakah mereka telah bekerja secara efektif atau tidak.

\section{Gross Profit Margin (GPM)}

Gross Profit Margin (GPM) mengukur persentase dari laba kotor dibandingkan dengan penjualan. Semakin baik gross profit margin maka semakin baik operasional perusahaan. Tetapi perlu diperhatikan bahwa gross profit margin sangat dipengaruhi oleh harga pokok penjualan. Gross profit margin dapat dihitung dengan rumus sebagai berikut:

$$
\mathrm{GPM}=\frac{\text { Laba Kotor }}{\text { Penjualan }} \times 100 \%
$$

\section{Operating Profit Margin (OPM)}

Operating Profit Margin (OPM) merupakan rasio yang digunakan untuk mengukur besarnya persentase laba operasional atas penjualan bersih. Hery (2016) mengungkapkan bahwa semakin tinggi margin laba operasi berarti semakin tinggi pula laba operasi yang dihasilkan dari penjualan bersih. Hal ini dapat disebabkan karena tingginya laba kotor dan rendahnya beban operasi. OPM dapat dihitung dengan rumus sebagai berikut:

$$
\mathrm{OPM}=\frac{\text { Laba Operasional }}{\text { Penjualan }} \times 100 \%
$$

\section{Net Profit Margin (NPM)}

Net Profit Margin (NPM) merupakan rasio yang digunakan untuk mengukur besarnya persentase laba bersih atas penjualan bersih (Hery, 2016). Rasio ini berfungsi untuk mengukur tingkat 
kembalian keuntungan bersih terhadap penjualan bersihnya. Hal ini mengindikasikan seberapa baik perusahaan dalam menggunakan biaya operasional karena menghubungkan laba bersih dengan penjualan bersih. Semakin tinggi Net Profit Margin maka semakin baik operasi perusahaan. Net Profit Margin dihitung dengan menggunakan rumus:

$$
\mathrm{NPM}=\frac{\text { Laba Bersih Sesudah Pajak }}{\text { Penjualan }} \times 100 \%
$$

\section{Return On Investment (ROI)}

Return On Investment (ROI) merupakan rasio yang mengukur kemampuan perusahaan dengan keseluruhan dana yang ditanamkan dalam aktivas yang digunakan untuk operasional suatu perusahaan guna menghasilkan suatu keuntungan (Munawir, 2016). Besarnya ROI dapat dihitung dengan rumus:

$$
\text { ROI }=\frac{\text { Laba Bersih Sesudah Pajak }}{\text { Total Investasi }} \times 100 \%
$$

\section{Return On Equity (ROE)}

Return on Equity (ROE) merupakan rasio yang mengukur laba bersih sesudah pajak dengan modal sendiri. Semakin tinggi ROE, semakin besar laba yang dihasilkan dari sejumlah dana yang diinvestasikan sehingga mencerminkan tingkat kesehatan keuangan perusahaan. Semakin tinggi rasio ini maka perusahaan tersebut semakin baik, artinya posisi pemilik perusahaan semakin kuat begitupun sebaliknya (Kasmir, 2017). ROE diperoleh dengan rumus sebagai berikut:

$$
\text { ROE }=\frac{\text { Laba Bersih Sesudah Pajak }}{\text { Modal Sendiri }} \times 100 \%
$$

Untuk mengetahui indikator-indikator yang mempengaruhi potensi perolehan laba dimasa depan, salah satu metode yang digunakan untuk menghitung ROE adalah dengan metode DupPont atau sering disebut sebagai analisis DuPont (Aries, 2011). Analisis menggunakan metode ini didasarkan pada rumus sebagai berikut:

$$
\begin{aligned}
& \text { ROE }=\text { Profit Margin } \times \text { Asset Turn Over } \times \text { Equity Multiplier } \\
& R O E=\left(\frac{\text { Net Income }}{\text { Sales }}\right) \times\left(\frac{\text { Sales }}{\text { Total Equity }}\right) \times\left(\frac{\text { TotalAsset }}{\text { TotalEquity }}\right)
\end{aligned}
$$

\section{Return On Asset (ROA)}

Return On Asset (ROA) merupakan rasio yang menunjukkan seberapa besar kontribusi aset dalam menciptakan laba bersih (Hery, 2016). Rasio ini dihitung dengan membagi laba bersih dengan total asset yang dimiliki. ROA dapat diukur dengan menggunakan rumus:

$$
\text { ROA }=\frac{\text { Laba Bersih Sesudah Pajak }}{\text { Total Aset }} \times 100 \%
$$


Menurut Hanafi dan Halim (2016), ROA merupakan rasio yang mengukur kemampuan perusahaan menghasilkan laba dengan menggunakan total aset (kekayaan) yang dipunyai perusahaan setelah disesuaikan dengan biaya-biaya untuk mendanai aset tersebut.

\section{Rasio Likuiditas}

Rasio likuiditas menunjukkan kemampuan perusahaan dalam membayar kewajiban perusahaan (utang). Likuiditas setiap perusahaan dapat bervariasi sesuai dengan life cycle perusahaan, keadaan makro ekonomi dan faktor-faktor internal lainnya. Pengukuran Likuiditas suatu perusahaan menggunakan indikator sebagai berikut.

\section{Current Ratio}

Current ratio yaitu rasio yang digunakan untuk mengukur kemampuan suatu perusahaan membayar kewajiban jangka pendeknya. Bila hasil perhitungan current ratio rendah, menunjukkan bahwa perusahaan kurang mampu membayar kewajibannya secara tepat waktu dengan menggunakan sumber daya aset lancar yang dimilikinya. Sebaliknya jika current ratio lebih tinggi mengindikasikan bahwa perusahaan cukup liquid dan mampu membayar kewajiban jangka pendeknya dengan baik.

$$
\text { Current Ratio }=\frac{\text { Aset lancar }}{\text { Utang Lancar }} \times 100 \%
$$

\section{Quick Ratio}

Kemampuan perusahaan untuk melakukan pembayaran kewajiban saat ini. Bila quick ratio tinggi menunjukkan perusahaan memiliki kas atau aset setara kas di tangan yang cukup untuk memenuhi kewajiban jangka pendeknya. Sebaliknya jika quick ratio rendah, mengindikasikan ketidakmampuan perusahaan menggunakan kas atau aset setara kas untuk memenuhi kewajiban jangka pendeknya.

$$
\text { Quick Ratio }=\frac{(\text { Kas }+ \text { Piutang })}{\text { Utang Lancar }} \times 100 \%
$$

\section{Rasio Solvabilitas}

Menurut Kasmir (2017) rasio solvabilitas atau leverage merupakan rasio yang digunakan untuk mengukur sejauh mana aktiva perusahaan dibiayai dengan hutang. Artinya seberapa besar beban hutang yang ditanggung perusahaan dibandingkan dengan aktivanya.

\section{Debt to Assets Ratio (DAR)}

Debt to Assets Ratio (DAR) digunakan untuk mengukur persentase besarnya dana atau modal yang disediakan oleh kreditur. Semakin tinggi rasio DAR berarti semakin besar modal pinjaman yang digunakan untuk menghasilkan keuntungan bagi perusahaan. DAR dapat dihitung dengan rumus:

$$
\text { DAR }=\frac{\text { Total Hutang }}{\text { Total Aset }}
$$




\section{Debt to Equity Ratio (DER)}

Debt to Equity Ratio (DER) digunakan untuk mengukur kemampuan perusahaan dalam memenuhi kewajiban dalam membayar hutangnya dengan jaminan modal sendiri. Selain itu rasio ini juga bisa digunakan untuk mengukur perimbangan antara kewajiban yang dimiliki perusahaan dengan modal sendiri. Semakin tinggi rasio DER berarti modal sendiri yang digunakan semakin sedikit dibanding dengan hutangnya. DER dapat dihitung dengan rumus:

$$
\text { DER }=\frac{\text { Total Hutang }}{\text { Modal Sendiri }}
$$

\section{Longterm Debt to Assets Ratio (LDAR)}

Longterm Debt to Assets Ratio (LDAR) digunakan untuk mengukur seberapa hutang jangka panjang digunakan untuk investasi pada sektor aktiva. Perhitungan LDAR dilakukan dengan menggunakan rumus:

$$
\text { LDAR }=\frac{\text { Hutang Jangka Panjang }}{\text { Total Aset }}
$$

\section{Longterm Debt to Equity Ratio (LDER)}

Longterm Debt to Equity Ratio (LDER) menunjukkan hubungan antara jumlah pinjaman jangka panjang yang diberikan kreditur dengan jumlah modal sendiri yang diberikan oleh pemilik perusahaan. Perhitungan LDER dilakukan dengan menggunakan rumus:

$$
\text { LDER }=\frac{\text { Hutang Jangka Panjang }}{\text { Modal Sendiri }}
$$

\section{Proyeksi Terhadap Kinerja Mendatang}

Menurut Djaja (2018) dengan melakukan analisis terhadap kinerja keuangan historis, penilai mendapatkan gambaran umum bagaimana perusahaan akan berevolusi dari tahun ke tahun dan pencapaian apa saja yang telah diperoleh dari perusahaan. Kunci utama proyeksi kinerja keuangan adalah membangun sudut pandang bagaimana arah perusahaan ke depan dengan mengestimasi pertumbuhan (growth) dan ROIC (Return on Invested Capital). Dalam menentukan jangka waktu periode proyeksi eksplisit perlu memperhatikan beberapa faktor seperti siklus kehidupan (lifecycle) produk; jumlah tahun yang dianggap cukup memadai (reasonable) dan dapat mewakili arus kas (cash flow); ketentuan umum tentang industrinya; kondisi makro ekonomi dan faktor internal dan eksternal lainnya. Indikator kondisi arus kas perusahaan mencapai kondisi yang stabil antara lain tingkat growth ke depan diharapkan wajar dan tidak terdapat lonjakan yang signifikan, pengeluaran untuk barang modal (capital expenditure) sejajar dengan tingkat penyusutan, tingkat kerugian pajak sudah dimanfaatkan (tax losses utilized), tingkat pajak ditangguhkan (deferred tax asset) sudah mencapai kestabilan serta siklus hidup perusahaan sudah mencapai tahap yang stabil. 


\section{Struktur Modal}

Struktur modal adalah merupakan perimbangan jumlah utang jangka pendek yang bersifat permanen, utang jangka panjang, saham preferen dan saham biasa (Hamidah, 2019). Beberapa teori struktur modal yang telah dikembangkan untuk menganalisis pengaruh penggunaan utang terhadap nilai perusahaan dan biaya modal yang pada dasarnya digunakan untuk menjawab 2 (dua) pertanyaan yaitu: dapatkah suatu perusahaan meningkatkan kemakmuran pemegang sahamnya dengan cara menggantikan sebagian modal sendiri dengan utang? dan seberapa besar utang yang harus dipergunakan oleh perusahaan?

Teori struktur modal pada awalnya dikembangkan oleh Franco Modigliani dan Merton Miller (MM) (1958) dengan menggunakan pendekatan struktur modal tanpa pajak sehingga "jika tidak ada pajak, struktur modal tidak mempengaruhi nilai perusahaan (irrelevance)". Kemudian MM mengembangkan teori struktur modal tersebut dengan memasukkan komponen pajak yang mengakibatkan pembayaran bunga atas utang akan mengurangi penghasilan kena pajak (tax deductible). Dengan pendekatan yang memasukkan unsur pajak menjadikan nilai perusahaan akan maksimum jika perusahaan menggunakan utang $100 \%$ atau yang disebut dengan corner optimum leverage decision.

Dalam kondisi normal tentunya akan sulit ditemui penggunaan utang $100 \%$ untuk modal, karena semakin tinggi utang akan semakin besar beban yang akan ditanggung oleh perusahaan seperti adanya agency cost, biaya kebangkrutan, keengganan dari kreditur untuk memberikan utang yang besar dan lain sebagainya. Karena itu muncul teori yang dikembangkan oleh Brealy dan Myers pada tahun 1991 yaitu trade-off theory yang mana struktur modal optimal tercapai pada saat terjadi keseimbangan antara manfaat dan pengorbanan yang timbul akibat penggunaan utang.

Trade-off theory dalam menentukan struktur modal yang optimal memasukan beberapa faktor seperti pajak, biaya keagenan (agency costs) dan biaya kesulitan keuangan (financial distress), namun tetap dengan menggunakan asumsi efisiensi pasar dan simetris informasi sebagai imbangan dan manfaat penggunaan hutang. Trade-off theory mempunyai implikasi bahwa manager akan memperhatikan penghematan pajak dan biaya kesulitan dalam penentuan struktur modal perusahaan. Hubungan antara nilai sekarang, financial distress dan agency cost dapat dilihat pada gambar 1.

Pada VL menunjukkan nilai perusahaan dengan utang dan merupakan dihitung dengan persamaan linear. Jika diperhitungkan nilai financial distress costs maka nilai aktual perusahaan akan mencapai titik tertinggi pada titik VL*, lalu kemudian turun kembali. Dengan demikian bahwa tingkat utang optimal berada di titik $\mathrm{D}^{*}$ 


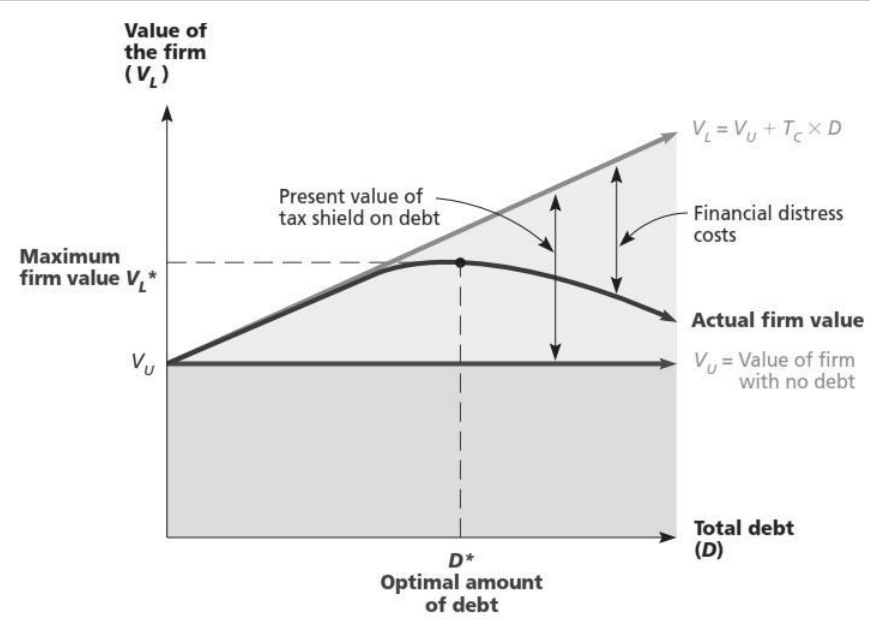

Pengaruh Levarage Terhadap Nilai Perusahaan

\section{Gambar 1 Pengaruh Levarage Terhadap Nilai Perusahaan}

\section{Nilai Perusahaan}

Beberapa konsep yang menjelaskan nilai suatu perusahaan menurut Christiawan dan Tarigan (2007) adalah sebagai berikut: Nilai Nominal, Nilai Pasar, Nilai Intrinsik, Nilai Buku, Nilai Likuidasi, Menurut Damodaran (2012), secara garis besar terdapat 3 (tiga) pendekatan yang digunakan dalam melakukan valuasi (penilaian) perusahaan, yaitu Discounted Cash Flow Valuation, Relative Valuation dan Contingent Claim Valuation.

\section{Discounted Cash Flow (DCF)}

Discounted Cash Flow (DCF) adalah salah satu metode valuasi dengan menggunakan pendekatan fundamental analisis dan merupakan dasar untuk metode valuasi lainnya. Secara umum, rumus DCF adalah sebagai berikut ini (Damodaran, 2012).

$$
\text { Value }=\sum_{t=1}^{t=n} \frac{C F_{t}}{(1+r)^{t}}
$$

Keterangan:

$\mathrm{n} \quad=$ Umur aset

$\mathrm{CFt}=$ Cash Flow pada waktu ke $\mathrm{t}$

$\mathrm{r} \quad=$ Suku bunga diskonto (discount rate)

Metode valuasi DCF memiliki tiga variasi perhitungan yang dapat digunakan untuk melakukan analisis valuasi saham yang sesuai dengan kebutuhan masing-masing analisis. Ketiga variasi tersebut adalah dividend discounted model, free cash flow to equity dan free cash flow to the firm. Untuk valuasi terhadap ekuitas perusahaan (equity valuation) akan menggunakan free cash flow to equity, sedangkan valuasi terhadap seluruh perusahaan (firm valuation) akan menggunakan free cash flow to the firm. 


\section{Tahapan Discounted Value}

Dalam melakukan penilaian perusahaan dengan model discounted cash flow menurut Djaja (2017) ada beberapa tahap yang perlu dilakukan. Tahapan tersebut adalah (1) melakukan analisis kinerja historis; (2) melakukan proyeksi terhadap kinerja mendatang; (3) menentukan Discount Rate; (4) menentukan terminal value dan (5) menghitung dan melakukan interpretasi atas hasil penilaian.

Untuk menentukan discount rate adalah dengan menghitung cost of capital yang dipakai untuk menentukan diskonto arus kas bersih masa akan datang (future free cash flow) ke posisi sekarang atau ke posisi cut off saat penilaian dilakukan. Cost of capital dihitung berdasarkan biaya modal rata-rata tertimbang (Weighted Average Cost of Capital/WACC) dengan rumus:

$$
W A C C=K e\left(\frac{E}{V}\right)+K d(1-t)\left(\frac{D}{V}\right)
$$

Keterangan:

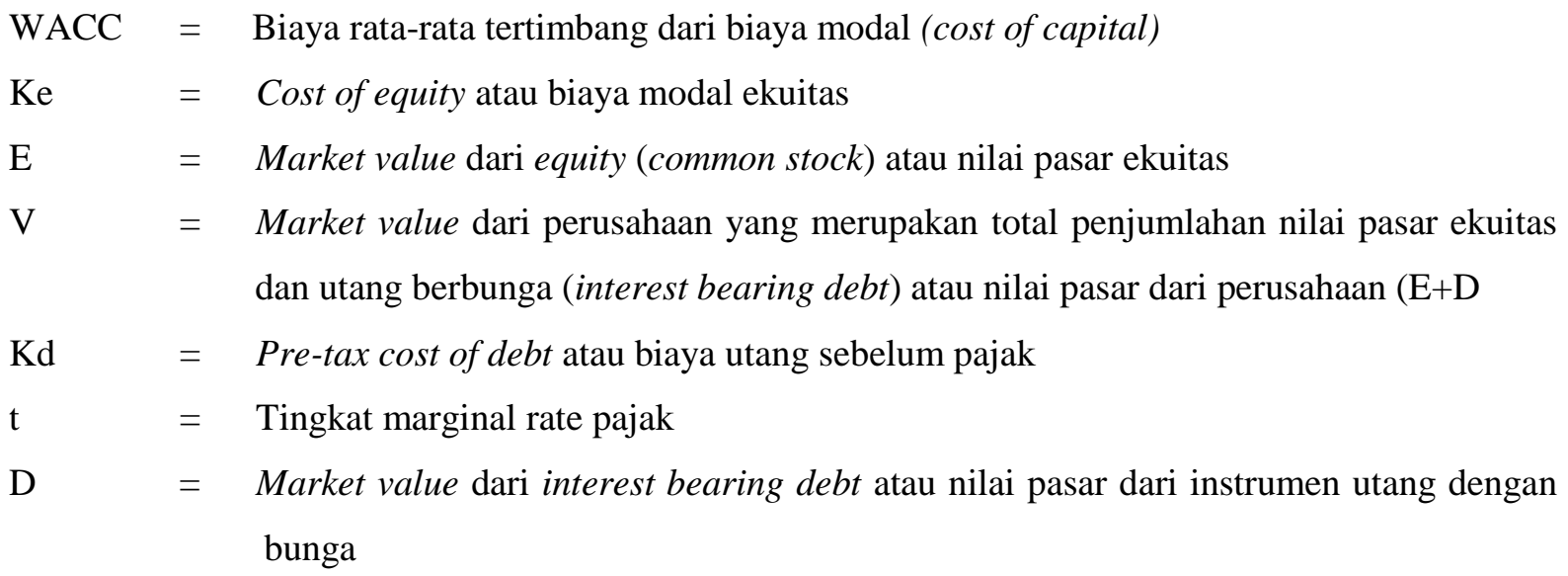

Salah satu komponen dalam perhitungan biaya modal rata-rata (WACC) adalah biaya ekuitas $(\mathrm{Ke})$. Metode yang digunakan untuk menentukan biaya ekuitas adalah metode Capital Asset Pricing Model (CAPM) yang merupakan metode paling popular untuk menghitung biaya ekuitas karena metode ini mendeskripsikan hubungan antara risk dan return dari sekuritas-sekuritas yang membentuk portofolio investasi dan digunakan untuk menentukan harga sekuritas yang berisiko.

Persamaan untuk mengetahui biaya ekuitas dengan menggunakan metode CAPM adalah sebagai berikut:

$$
K e=R f+\beta i(E(r m)-R f)
$$

Keterangan:

$\begin{array}{ll}\mathrm{Ke} & =\text { Cost of Equity } \\ \mathrm{Rf} & =\text { Suku bunga bebas risiko (risk free rate) } \\ \beta \mathrm{i} & =\text { Beta instrument } \mathrm{i} \\ \mathrm{E}(\mathrm{rm}) & =\text { tingkat return pasar } \\ (\mathrm{E}(\mathrm{rm})-\mathrm{Rf}) & =\text { Premium risiko pasar (market risk premium) }\end{array}$




\section{Kerangka Analisis}

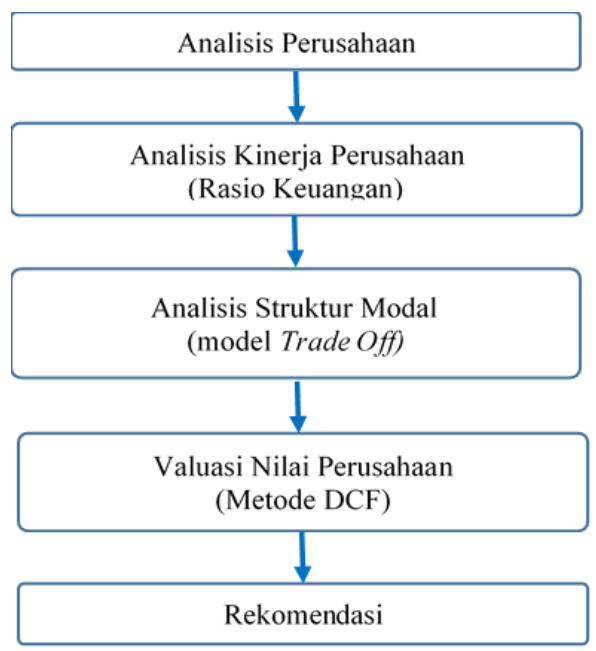

Gambar 2 Kerangka Analisis

\section{METODE RISET}

Metode yang digunakan dalam penelitian ini adalah metode studi kasus (case study). Tujuan dari studi kasus adalah untuk memberikan gambaran secara mendetail tentang latar belakang, sifat-sifat serta karakter-karakter yang khas dari kasus, ataupun status dari individu, yang kemudian dari sifatsifat khas akan dijadikan suatu hal yang bersifat umum.

Objek penelitian ini adalah PT. Trans Marga Jateng dan PT. Jasamarga Surabaya Mojokerto yang merupakan Anak Perusahaan Jalan Tol milik Jasa Marga yang saat ini sudah mulai solvent yaitu mampu memenuhi kewajiban hutangnya dan direncanakan akan dilakukan restrukturisasi atas hutangnya guna meningkatkan kinerja keuangan seiring dengan telah beroperasinya jalan tol perusahaan secara penuh. Jenis data yang digunakan dalam penelitian ini yaitu:

1. Data Primer (Primary Data) merupakan data yang didapat dari sumber pertama. Data ini didapatkan secara langsung dari PT. Trans Marga Jateng dan PT. Jasamarga Surabaya Mojokerto melalui proses wawancara.

2. Data Sekunder (Secondary Data) merupakan data yang diperoleh secara tidak langsung tetapi melalui sumber lain. Sumber data sekunder yang digunakan dalam penelitian ini berasal dari buku literatur, jurnal-jurnal keuangan, informasi dari internet dan laporan keuangan perusahaan.

\section{HASIL PENELITIAN DAN PEMBAHASAN}

Pengukuran kinerja perusahaan dilakukan melalui analisis laporan keuangan yang terdiri dari perhitungan rasio keuangan perusahaan dengan 3 (tiga) indikator yaitu rasio profitabilitas, rasio likuiditas dan rasio solvabilitas. Berikut merupakan penilaian kinerja perusahaan dari PT. Trans Marga 
Jateng (PT. TMJ) dan PT. Jasamarga Surabaya Mojokerto (PT. JSM) dengan menggunakan perhitungan rasio keuangan.

\section{Rasio Profitabilitas}

Rasio profitabilitas untuk memberikan gambaran mengenai kemampuan perusahaan dalam menghasilkan laba dan evaluasi terhadap efektivitas kinerja manajemen. Indikator yang digunakan digunakan untuk mengukur tingkat profitabilitas adalah melalui perhitungan rasio gross profit margin, operating profit margin, net profit margin, return on investment, return on asset dan return on equity. Hasil perhitungan atas rasio profitabilitas PT. TMJ dan PT. JSM adalah sebagai berikut:

Tabel 1. Rasio Profitabilitas PT. TMJ dan PT. JSM Tahun 2015-2019

\begin{tabular}{|c|c|c|c|c|c|c|c|c|c|c|}
\hline \multirow{2}{*}{ Rasio } & \multicolumn{5}{|c|}{ PT TMJ } & \multicolumn{5}{|c|}{ PT JSM } \\
\hline & 2015 & 2016 & 2017 & 2018 & 2019 & 2015 & 2016 & 2017 & 2018 & 2019 \\
\hline GPM & $54,62 \%$ & $55,29 \%$ & $54,14 \%$ & $50,98 \%$ & $68,99 \%$ & $26,45 \%$ & $30,36 \%$ & $37,97 \%$ & $71,29 \%$ & $77,21 \%$ \\
\hline OPM & $49,98 \%$ & $44,97 \%$ & $44,27 \%$ & $38,25 \%$ & $64,06 \%$ & $-7,48 \%$ & $13,66 \%$ & $14,71 \%$ & $63,40 \%$ & $73,11 \%$ \\
\hline NPM & $-41,76 \%$ & $-10,24 \%$ & $-30,75 \%$ & $-110,76 \%$ & $-16,60 \%$ & $-5,65 \%$ & $-11,72 \%$ & $-9,25 \%$ & $-62,95 \%$ & $-20,71 \%$ \\
\hline ROI & $-4,49 \%$ & $-2,59 \%$ & $-3,93 \%$ & $-5,80 \%$ & $-1,61 \%$ & $-1,49 \%$ & $-2,47 \%$ & $-3,02 \%$ & $-4,06 \%$ & $-1,77 \%$ \\
\hline $\mathrm{ROE}$ & $-7,60 \%$ & $-5,99 \%$ & $-11,05 \%$ & $-17,66 \%$ & $-4,64 \%$ & $-3,54 \%$ & $-6,81 \%$ & $-9,22 \%$ & $-14,65 \%$ & $-6,50 \%$ \\
\hline ROA & $-4,75 \%$ & $-2,85 \%$ & $-4,64 \%$ & $-7,29 \%$ & $-1,86 \%$ & $-1,47 \%$ & $-2,54 \%$ & $-2,82 \%$ & $-4,45 \%$ & $-1,98 \%$ \\
\hline
\end{tabular}

Sumber: Data diolah

Dari hasil perhitungan rasio profitabilitas menunjukan bahwa kinerja PT. TMJ mengalami peningkatan di tahun 2019 jika dibandingkan dengan tahun 2018. Hal tersebut dikarenakan sejak awal tahun 2019 ruas jalan tol PT. TMJ telah beroperasi penuh dan terhubung dengan ruas jalan tol trans jawa sehingga meningkatkan pendapatan tol serta perusahaan juga melakukan berbagai upaya untuk mengendalikan biaya operasional yang dapat meningkatkan efisiensi kinerja sehingga menghasilkan keuntungan yang lebih besar. Kinerja rasio profitabilitas PT. TMJ pada tahun 2015-2018 yang cenderung fluktuatif antara lain Gross Profit Margin, Net Profit Margin, Return on Investment, Return on Equity, dan Return on Asset. Hal tersebut dikarenakan pengoperasian jalan tol PT. TMJ yang dilakukan secara bertahap dan kegiatan percepatan pembangunan proyek jalan tol yang membuat peningkatan nilai investasi dan peningkatan aset.

Hal yang sama juga ditunjukan oleh hasil perhitungan atas semua indikator profitabilitas PT. JSM yang mengalami peningkatan di tahun 2019 jika dibandingkan dengan tahun 2018 dan tahun-tahun sebelumnya yang cenderung fluktuatif. Untuk indikator Net Profit Margin, PT. JSM tahun 2015-2018 cenderung menurun disebabkan karena pengoperasian jalan tol PT. JSM yang dilakukan secara bertahap dan timbulnya beban keuangan untuk pembayaran bunga kredit investasi.

Dari analisis Du-Pont atas komponen rasio Return on Equity dapat diketahui bahwa tingkat pengembalian atas investasi PT. TMJ dan PT. JSM masih bernilai negatif dikarenakan peningkatan nilai aset lebih banyak dibiayai oleh utang sehingga hasil usaha yang diperoleh masih digunakan untuk menyelesaikan kewajiban utang. Strategi yang dapat digunakan oleh manajemen PT. TMJ dan PT. JSM untuk meningkatkan kinerja keuangan dalam pengembalian tingkat investasi adalah dengan 
meningkatkan pendapatan dan melakukan program efisiensi biaya operasi serta strategi restrukturisasi utang guna memperoleh biaya keuangan yang lebih murah.

\section{Rasio Likuiditas}

Rasio likuiditas memberikan informasi mengenai kemampuan perusahaan untuk memenuhi kewajiban finansial jangka pendeknya. Tujuan dari perhitungan rasio ini adalah untuk menilai kemampuan PT. TMJ dan PT. JSM untuk membayar utang perusahaan dalam waktu jangka pendek tanpa mengalami financial distress. Rasio likuiditas dihitung melalui perhitungan current ratio dan quick ratio. Hasil perhitungan rasio likuiditas adalah sebagai berikut:

Tabel 2 Rasio Likuiditas PT. TMJ dan PT. JSM Tahun 2015-2019

\begin{tabular}{|c|c|c|c|c|c|c|c|c|c|c|}
\hline \multirow{2}{*}{ Rasio } & \multicolumn{5}{|c|}{ PT TMJ } & \multicolumn{5}{|c|}{ PT JSM } \\
\hline & 2015 & 2016 & 2017 & 2018 & 2019 & 2015 & 2016 & 2017 & 2018 & 2019 \\
\hline $\begin{array}{c}\text { Current } \\
\text { Ratio }\end{array}$ & $17,44 \%$ & $48,67 \%$ & $66,09 \%$ & $75,24 \%$ & $26,66 \%$ & $179,25 \%$ & $42,34 \%$ & $13,62 \%$ & $25,63 \%$ & $12,04 \%$ \\
\hline $\begin{array}{l}\text { Quick } \\
\text { Ratio }\end{array}$ & $17,26 \%$ & $48,59 \%$ & $65,56 \%$ & $74,66 \%$ & $26,48 \%$ & $147,32 \%$ & $33,40 \%$ & $13,11 \%$ & $25,37 \%$ & $11,93 \%$ \\
\hline
\end{tabular}

Dari perhitungan rasio-rasio likuiditas di atas terlihat bahwa Current Ratio dan Quick Ratio PT. TMJ mengalami peningkatan sejak tahun 2015 dan mengalami penurunan pada tahun 2019. Hal ini disebabkan pada tahun 2019 jalan tol PT. TMJ telah beroperasi penuh sehingga pembayaran kewajiban jangka pendek mulai dilaksanakan untuk pembayaran utang kontraktor. Hal yang sama juga ditunjukkan dengan hasil perhitungan rasio likuiditas PT. JSM, dimana Current Ratio mengalami penurunan pada tahun 2019 jika dibandingkan dengan tahun 2018 karena timbulnya kewajiban jangka pendek berupa utang kontraktor dengan selesainya konstruksi proyek-proyek pembangunan jalan tol.

\section{Rasio Solvabilitas}

Rasio ini untuk melihat kemampuan perusahaan dalam memenuhi semua kewajibankewajibannya dengan menggunakan seluruh aset yang dimiliki. Rasio Solvabilitas dihitung melalui perhitungan debt to asset ratio, debt to equity ratio, long term debt to asset ratio, dan long term debt to equity ratio. Hasil pengukuran rasio solvabilitas dapat dilihat pada tabel berikut:

Tabel 3 Rasio Solvabilitas PT. TMJ dan PT. JSM Tahun 2015-2019

\begin{tabular}{|c|c|c|c|c|c|c|c|c|c|c|}
\hline \multirow{2}{*}{ Rasio } & \multicolumn{5}{|c|}{ PT TMJ } & \multicolumn{5}{|c|}{ PT JSM } \\
\hline & 2015 & 2016 & 2017 & 2018 & 2019 & 2015 & 2016 & 2017 & 2018 & 2019 \\
\hline DAR & $43,15 \%$ & $62,47 \%$ & $75,99 \%$ & $84,45 \%$ & $75,89 \%$ & $57,32 \%$ & $65,52 \%$ & $62,80 \%$ & $79,62 \%$ & $82,19 \%$ \\
\hline DER & $68,98 \%$ & $131,47 \%$ & $180,82 \%$ & $204,61 \%$ & $189,04 \%$ & $138,13 \%$ & $175,46 \%$ & $205,57 \%$ & $262,07 \%$ & $269,92 \%$ \\
\hline LDAR & $38,36 \%$ & $48,75 \%$ & $65,98 \%$ & $77,12 \%$ & $75,74 \%$ & $57,28 \%$ & $58,76 \%$ & $61,54 \%$ & $78,57 \%$ & $75,32 \%$ \\
\hline LDER & $61,31 \%$ & $102,59 \%$ & $157,00 \%$ & $186,84 \%$ & $188,65 \%$ & $138,04 \%$ & $157,34 \%$ & $201,42 \%$ & $258,62 \%$ & $247,35 \%$ \\
\hline
\end{tabular}

Dari hasil pengukuran tingkat solvabilitas dari PT. TMJ tahun 2019 di atas terlihat bahwa tahun 2019 lebih rendah dibandingkan dengan tahun 2018. Hal ini disebabkan karena adanya repackaging pembiayaan atas utang investasi yang dilakukan oleh PT. TMJ disamping terdapat kenaikan nilai aset. $\underline{\text { Pada PT. JSM rasio solvabilitas di tahun } 2019 \text { meningkat dari tahun } 2018 \text { dikarenakan adanya }}$ 
Murtianto, A., Akbar, M. T., dan Hendriyeni, N. S., (2021). Nilai Perusahaan pada Struktur ....

peningkatan jumlah utang pada tahun 2019 karena penarikan kredit investasi untuk pembayaran kewajiban utang kontraktor karena selesainya pembangunan proyek jalan tol PT. JSM.

\section{Proyeksi Rasio Profitabilitas}

Proyeksi kinerja perusahaan Proyeksi akan memudahkan perusahaan melihat apa yang terjadi beberapa tahun yang akan datang. Dalam melakukan proyeksi mempertimbangkan karakteristik industri dan memperhatikan kemampuan bersaing (kelebihan dan kekurangan), kejadian-kejadian penting yang mungkin mempengaruhi kinerja perusahaan, indikator-indikator utama perusahaan (key value drivers) yang mempengaruhi nilai perusahaan seperti pertumbuhan pendapatan, tingkat suku bunga pinjaman, tingkat inflasi dan tarif pajak perusahaan. Hasil perhitungan proyeksi rasio profitabilitas dapat dilihat pada tabel berikut ini:

Tabel 4 Proyeksi Rasio Profitabilitas PT. TMJ dan PT. JSM Tahun 2020-2024

\begin{tabular}{|c|c|c|c|c|c|c|c|c|c|c|}
\hline \multirow{2}{*}{ Rasio } & \multicolumn{5}{|c|}{ PT TMJ } & \multicolumn{5}{|c|}{ PT JSM } \\
\hline & 2020 & 2021 & 2022 & 2023 & 2024 & 2020 & 2021 & 2022 & 2023 & 2024 \\
\hline GPM & $76,34 \%$ & $80,44 \%$ & $81,86 \%$ & $82,96 \%$ & $83,12 \%$ & $75,73 \%$ & $75,82 \%$ & $76,69 \%$ & $76,89 \%$ & $78,44 \%$ \\
\hline OPM & $72,41 \%$ & $77,55 \%$ & $79,27 \%$ & $80,54 \%$ & $80,74 \%$ & $70,53 \%$ & $70,78 \%$ & $71,93 \%$ & $72,14 \%$ & $73,97 \%$ \\
\hline NPM & $3,63 \%$ & $14,18 \%$ & $23,02 \%$ & $25,86 \%$ & $29,38 \%$ & $-5,24 \%$ & $1,02 \%$ & $10,38 \%$ & $15,57 \%$ & $26,01 \%$ \\
\hline ROI & $0,36 \%$ & $1,64 \%$ & $3,22 \% \mathrm{~A}$ & $4,29 \%$ & $5,52 \%$ & $-0,56 \%$ & $0,12 \%$ & $1,37 \%$ & $2,26 \%$ & $4,53 \%$ \\
\hline ROE & $1,14 \%$ & $5,14 \%$ & $9,83 \%$ & $12,44 \%$ & $15,13 \%$ & $-2,07 \%$ & $0,43 \%$ & $4,97 \%$ & $7,97 \%$ & $15,06 \%$ \\
\hline ROA & $0,45 \%$ & $1,97 \%$ & $3,72 \%$ & $4,70 \%$ & $5,78 \%$ & $-0,64 \%$ & $0,14 \%$ & $1,59 \%$ & $2,61 \%$ & $5,05 \%$ \\
\hline
\end{tabular}

Sumber: data diolah

Hasil proyeksi untuk 5 (lima) tahun ke depan PT. TMJ menunjukan bahwa PT. TMJ mengalami pertumbuhan positif dikarenakan jalan tol Semarang-Solo sudah beroperasi secara penuh pada awal tahun 2019 sehingga meningkatkan volume lalu lintas dan pendapatan tol. Kenaikan pendapatan cukup signifikan diasumsikan terjadi pada tahun 2021 karena adanya perubahan tarif per kilometer atas ruas jalan tol Semarang-Solo dan penurunan beban usaha perusahaan. Untuk PT. JSM, dapat dilihat bahwa indikator-indikator pada proyeksi rasio profitabilitas mengalami pertumbuhan yang positif dari tahun 2020 sampai dengan tahun 2024. Hal ini dikarenakan adanya asumsi kenaikan pendapatan usaha dan laba usaha sebesar $13,2 \%$ per tahun.

\section{Proyeksi Rasio Likuiditas}

Perhitungan Proyeksi Rasio Likuiditas dapat dilihat pada tabel berikut ini:

Tabel 5 Proyeksi Rasio Likuiditas PT. TMJ dan PT. JSM Tahun 2020-2024

\begin{tabular}{|c|c|c|c|c|c|c|c|c|c|c|}
\hline \multirow{2}{*}{ Rasio } & \multicolumn{5}{|l|}{ PT TMJ } & \multicolumn{5}{|l|}{ PT JSM } \\
\hline & 2020 & 2021 & 2022 & 2023 & 2024 & 2020 & 2021 & 2022 & 2023 & 2024 \\
\hline $\begin{array}{l}\text { Current } \\
\text { Ratio }\end{array}$ & $412,17 \%$ & $11,92 \%$ & $18,42 \%$ & $29,52 \%$ & $29,80 \%$ & $40,32 \%$ & $60,75 \%$ & $67,92 \%$ & $62,41 \%$ & $57,03 \%$ \\
\hline $\begin{array}{l}\text { Quick } \\
\text { Ratio }\end{array}$ & $411,21 \%$ & $11,69 \%$ & $18,25 \%$ & $29,41 \%$ & $29,71 \%$ & $40,32 \%$ & $60,75 \%$ & $67,92 \%$ & $62,41 \%$ & $57,03 \%$ \\
\hline
\end{tabular}

Proyeksi atas rasio likuiditas untuk PT. TMJ selama 5 (lima) tahun ke depan menunjukkan adanya saldo kas yang cukup besar di tahun 2020 dikarenakan program repackaging pinjaman di tahun 
2019. Pertumbuhan rasio likuiditas di PT. JSM dari tahun 2020 menunjukkan bahwa perusahaan memiliki saldo cash yang bertumbuh karena operasional perusahaan berkembang dengan baik.

\section{Proyeksi Rasio Solvabilitas}

Perhitungan Proyeksi Rasio Solvabilitas dapat dilihat pada tabel berikut ini:

Tabel 6 Proyeksi Rasio Solvabilitas PT. TMJ dan PT. JSM Tahun 2020-2024

\begin{tabular}{|c|c|c|c|c|c|c|c|c|c|c|}
\hline \multirow{2}{*}{ Rasio } & \multicolumn{5}{|c|}{ PT TMJ } & \multicolumn{5}{|c|}{ PT JSM } \\
\hline & 2020 & 2021 & 2022 & 2023 & 2024 & 2020 & 2021 & 2022 & 2023 & 2024 \\
\hline DAR & $84,92 \%$ & $83,76 \%$ & $80,80 \%$ & $77,31 \%$ & $72,22 \%$ & $83,02 \%$ & $84,49 \%$ & $84,41 \%$ & $82,56 \%$ & $78,00 \%$ \\
\hline DER & $215,85 \%$ & $218,53 \%$ & $213,56 \%$ & $204,50 \%$ & $188,83 \%$ & $269,22 \%$ & $268,99 \%$ & $263,90 \%$ & $252,35 \%$ & $232,64 \%$ \\
\hline LDAR & $83,92 \%$ & $79,77 \%$ & $75,27 \%$ & $69,39 \%$ & $61,41 \%$ & $81,37 \%$ & $81,11 \%$ & $78,70 \%$ & $73,83 \%$ & $66,65 \%$ \\
\hline LDER & $213,30 \%$ & $208,13 \%$ & $198,94 \%$ & $183,57 \%$ & $160,58 \%$ & $263,86 \%$ & $258,23 \%$ & $246,07 \%$ & $225,69 \%$ & $198,80 \%$ \\
\hline
\end{tabular}

Proyeksi rasio solvabilitas PT. TMJ tahun 2020 sampai dengan tahun 2024 dapat kita lihat bahwa untuk 5 (lima) tahun kedepan mengalami pertumbuhan yang positif karena perusahaan dapat memenuhi kewajibannya. Hal yang sama juga terlihat pada proyeksi rasio solvabilitas PT. JSM tahun 2020 sampai dengan tahun 2024 cenderung menurun karena perusahaan telah mampu untuk memenuhi kewajibannya setiap tahun.

\section{Struktur Modal Perusahaan}

Struktur modal merupakan kombinasi penggunaan utang dan ekuitas dalam pemenuhan kebutuhan modal. Dalam kaitannya dengan nilai perusahaan, struktur modal bertujuan untuk menentukan komposisi utang dan ekuitas dalam jangka panjang yang optimal yang dapat memaksimalkan nilai perusahaan sehingga meningkatkan kekayaan pemegang saham (stockholder wealth).

\section{Pendekatan Trade-off theory}

Dengan menggunakan pendekatan Trade-off theory, maka dalam menentukan struktur modal optimal memasukkan beberapa faktor seperti pajak, biaya keagenan (agency costs) dan biaya kesulitan keuangan (financial distress) serta menggunakan skenario proporsi utang dan equity dari $0 \%$ sampai dengan 100. Hasil yang didapatkan dapat dilihat pada Tabel 7.

Dari hasil perhitungan nilai perusahaan $\left(\mathrm{V}_{\mathrm{L}}\right)$ dengan komposisi proporsi utang PT. TMJ terdapat kenaikan setiap 10\% dan dengan mempertimbangkan adanya financial distress dan agency cost, untuk tahun 2020-2024 terlihat bahwa nilai perusahaan tertinggi dicapai pada komposisi persentase utang sebesar $30 \%$. 
Murtianto, A., Akbar, M. T., dan Hendriyeni, N. S., (2021). Nilai Perusahaan pada Struktur ....

Tabel 7 Hasil Perhitungan VL PT. TMJ Tahun 2020 - 2024

Probability

Debt financial distres

VL

\begin{tabular}{|c|c|c|c|c|c|c|}
\hline & \multirow{2}{*}{ dan agency cost } & \\
\hline & & 2020 & 2021 & 2022 & 2023 & 2024 \\
\hline $0 \%$ & $0 \%$ & 4.864 .937 & 6.003 .054 & 7.177 .758 & 8.236 .299 & 8.867 .187 \\
\hline $10 \%$ & $1 \%$ & 4.984 .689 & 6.150 .821 & 7.354 .442 & 8.439 .039 & 9.085 .456 \\
\hline $20 \%$ & $4 \%$ & 5.080 .018 & 6.268 .452 & 7.495 .091 & 8.600 .430 & 9.259 .210 \\
\hline $30 \%$ & $9 \%$ & 5.117 .387 & 6.314 .563 & 7.550 .226 & 8.663 .696 & 9.327 .322 \\
\hline $40 \%$ & $16 \%$ & 5.059 .534 & 6.243 .176 & 7.464 .869 & 8.565 .751 & 9.221 .874 \\
\hline $50 \%$ & $25 \%$ & 4.864 .937 & 6.003 .054 & 7.177 .758 & 8.236 .299 & 8.867 .187 \\
\hline $60 \%$ & $36 \%$ & 4.487 .189 & 5.536 .934 & 6.620 .426 & 7.596 .775 & 8.178 .676 \\
\hline $70 \%$ & $49 \%$ & 3.874 .259 & 4.780 .614 & 5.716 .106 & 6.559 .089 & 7.061 .505 \\
\hline $80 \%$ & $64 \%$ & 2.967 .611 & 3.661 .863 & 4.378 .433 & 5.024 .142 & 5.408 .984 \\
\hline $90 \%$ & $81 \%$ & 1.701 .159 & 2.099 .132 & 2.509 .900 & 2.880 .048 & 3.100 .655 \\
\hline $100 \%$ & $95 \%$ & 324.329 & 400.204 & 478.517 & 549.087 & 591.146 \\
\hline & & & Data dic & & & \\
\hline
\end{tabular}

Tabel 8 Hasil Perhitungan VL PT. JSM Tahun 2020 - 2024

Probability

Debt financial distres

VL

\begin{tabular}{|c|c|c|c|c|c|c|}
\hline & dan agency cost & 2020 & 2021 & 2022 & 2023 & 2024 \\
\hline $0 \%$ & $0 \%$ & 3.718 .108 & 4.026 .536 & 4.612 .791 & 4.940 .053 & 5.731 .776 \\
\hline $10 \%$ & $1 \%$ & 3.809 .630 & 4.125 .650 & 4.726 .336 & 5.061 .654 & 5.872 .866 \\
\hline $20 \%$ & $4 \%$ & 3.882 .487 & 4.204 .551 & 4.816 .724 & 5.158 .455 & 5.985 .181 \\
\hline $30 \%$ & $9 \%$ & 3.911 .047 & 4.235 .480 & 4.852 .157 & 5.196 .401 & 6.029 .209 \\
\hline $40 \%$ & $16 \%$ & 3.866 .832 & 4.187.597 & 4.797.302 & 5.137 .655 & 5.961 .047 \\
\hline $50 \%$ & $25 \%$ & 3.718 .108 & 4.026 .536 & 4.612 .791 & 4.940 .053 & 5.731 .776 \\
\hline $60 \%$ & $36 \%$ & 3.429 .408 & 3.713 .887 & 4.254 .621 & 4.556 .472 & 5.286 .721 \\
\hline $70 \%$ & $49 \%$ & 2.960 .966 & 3.206 .587 & 3.673 .459 & 3.934 .078 & 4.564 .578 \\
\hline $80 \%$ & $64 \%$ & 2.268 .046 & 2.456 .187 & 2.813 .802 & 3.013 .432 & 3.496 .383 \\
\hline $90 \%$ & $81 \%$ & 1.300 .138 & 1.407 .989 & 1.612 .989 & 1.727 .425 & 2.004 .273 \\
\hline $100 \%$ & $95 \%$ & 247.874 & 268.436 & 307.519 & 329.337 & 382.118 \\
\hline
\end{tabular}

Dari hasil perhitungan nilai perusahaan $\left(\mathrm{V}_{\mathrm{L}}\right)$ dengan komposisi proporsi utang PT. JSM terdapat kenaikan setiap 10\% dan dengan mempertimbangkan adanya financial distress dan agency cost, untuk tahun 2020-2024 terlihat bahwa nilai perusahaan tertinggi dicapai pada komposisi persentase utang sebesar $30 \%$.

Dari tabel perhitungan nilai perusahaan PT. TMJ dan PT. JSM di atas menunjukkan bahwa nilai perusahaan mengalami kenaikan karena adanya efek dari tax benefit dari pinjaman (utang), namun tidak selalu naik sampai pada proporsi utang 100\% karena adanya efek dari financial distress cost dan agency cost. Terdapat titik dimana nilai perusahaan kembali mengalami penurunan sedangkan tingkat utang terus ditingkatkan. Hal tersebut terjadi karena probability financial distress cost dan agency cost yang terus mengalami kenaikan dan bahkan nilainya sudah melebihi tax benefit yang didapatkan oleh 
perusahaan melalui utang tersebut. Struktur modal yang menghasilkan nilai perusahaan paling besar berada pada proporsi utang $30 \%$ untuk setiap tahunnya.

\section{Biaya Modal Rata-Rata Tertimbang (WACC)}

Selain dengan menggunakan pendekatan trade off theory, pertimbangan selanjutnya dalam menentukan struktur modal optimal adalah menghitung biaya modal rata-rata tertimbang perusahaan (weighted average cost of capital (WACC). Struktur modal yang optimal dapat tercapai bila biaya modal minimum dan nilai perusahaan meningkat. Adapun hasil perhitungan biaya modal rata-rata tertimbang (WACC) PT. TMJ adalah sebagai berikut:

Tabel 9 Hasil Perhitungan WACC PT. TMJ

\begin{tabular}{rrrrr}
\multicolumn{2}{c}{ Struktur Modal } & \multirow{2}{*}{ Ksl } & \multicolumn{1}{l}{ Kd } & WACC \\
\cline { 1 - 4 } D & E & & & \\
\cline { 1 - 4 } $0 \%$ & $100 \%$ & $8,41 \%$ & $9,57 \%$ & $8,41 \%$ \\
$10 \%$ & $90 \%$ & $8,31 \%$ & $9,57 \%$ & $8,20 \%$ \\
$20 \%$ & $80 \%$ & $8,19 \%$ & $9,57 \%$ & $7,99 \%$ \\
$30 \%$ & $70 \%$ & $8,02 \%$ & $9,57 \%$ & $7,77 \%$ \\
$40 \%$ & $60 \%$ & $7,76 \%$ & $9,57 \%$ & $7,53 \%$ \\
$50 \%$ & $50 \%$ & $7,25 \%$ & $9,57 \%$ & $7,21 \%$ \\
$60 \%$ & $40 \%$ & $5,57 \%$ & $9,57 \%$ & $6,53 \%$ \\
$70 \%$ & $30 \%$ & $\infty$ & $9,57 \%$ & $\infty$ \\
$80 \%$ & $20 \%$ & $\infty$ & $9,57 \%$ & $\infty$ \\
$90 \%$ & $10 \%$ & $\infty$ & $9,57 \%$ & $\infty$ \\
$100 \%$ & $0 \%$ & $\infty$ & $9,57 \%$ & $\infty$ \\
\multicolumn{5}{c}{ Sumber: data diolah }
\end{tabular}

Dari tabel perhitungan WACC PT. TMJ di atas, dengan berbagai komposisi proporsi utang dapat diketahui bahwa nilai biaya modal rata-rata (WACC) yang paling rendah adalah pada komposisi $60 \%$ utang dan $40 \%$ ekuitas, yaitu sebesar 6,53\%. Dengan biaya modal rata-rata yang paling rendah, akan mendapatkan nilai perusahaan yang paling optimal. Sedangkan hasil perhitungan biaya modal rata-rata tertimbang (WACC) PT. JSM adalah sebagai berikut:

Tabel 10. Hasil Perhitungan WACC PT. JSM

\begin{tabular}{|c|c|c|c|c|}
\hline \multicolumn{2}{|c|}{ Struktur Modal } & \multirow{2}{*}{ Ksl } & \multirow{2}{*}{ Kd } & \multirow{2}{*}{ WACC } \\
\hline D & $\mathbf{E}$ & & & \\
\hline $0 \%$ & $100 \%$ & $8,41 \%$ & $9,80 \%$ & $8,41 \%$ \\
\hline $10 \%$ & $90 \%$ & $8,29 \%$ & $9,80 \%$ & $8,20 \%$ \\
\hline $20 \%$ & $80 \%$ & $8,14 \%$ & $9,80 \%$ & $7,99 \%$ \\
\hline $30 \%$ & $70 \%$ & $7,94 \%$ & $9,80 \%$ & $7,76 \%$ \\
\hline $40 \%$ & $60 \%$ & $7,63 \%$ & $9,80 \%$ & $7,52 \%$ \\
\hline $50 \%$ & $50 \%$ & $7,02 \%$ & $9,80 \%$ & $7,18 \%$ \\
\hline $60 \%$ & $40 \%$ & $5,00 \%$ & $9,80 \%$ & $6,41 \%$ \\
\hline $70 \%$ & $30 \%$ & $\infty$ & $9,80 \%$ & $\infty$ \\
\hline $80 \%$ & $20 \%$ & $\infty$ & $9,80 \%$ & $\infty$ \\
\hline $90 \%$ & $10 \%$ & $\infty$ & $9,80 \%$ & $\infty$ \\
\hline $100 \%$ & $0 \%$ & $\infty$ & $9,80 \%$ & $\infty$ \\
\hline
\end{tabular}


Hasil perhitungan WACC untuk PT. JSM, dengan berbagai komposisi proporsi utang dapat diketahui bahwa nilai biaya modal rata-rata (WACC) yang paling rendah adalah pada komposisi $60 \%$ utang dan $40 \%$ ekuitas, yaitu sebesar 6,41\%. Dengan biaya modal rata-rata yang paling rendah, akan mendapatkan nilai perusahaan yang paling optimal.

Berdasarkan hasil perhitungan tersebut, bisa diambil kesimpulan bahwa struktur modal yang optimal dengan mempertimbangkan nilai perusahaan dan biaya modal adalah berada di antara komposisi utang 60\%-40\%. Nilai WACC akan mulai mengalami peningkatan pada komposisi utang $70 \%$ karena nilai cost of equity levered perusahaan (Ksl) mengalami peningkatan sejak dari komposisi $70 \%$ utang.

\section{Valuasi Perusahaan}

Dari hasil penentuan struktur modal yang optimal diharapkan dapat menghasilkan nilai perusahaan yang maksimal. Untuk mengetahui nilai perusahaan, metode yang digunakan untuk melakukan penilaian (valuasi) perusahaan adalah dengan menggunakan metode valuasi Discounted Cash Flow. Hasil perhitungan valuasi perusahaan pada komposisi perbandingan debt dan equity maksimal (60:40) dan minimal (30:70) dengan metode Discounted Cash Flow adalah sebagai berikut:

Tabel 11. Laporan Penilaian Valuasi Perusahaan PT. TMJ

\begin{tabular}{ccc}
\hline & Maksimal & Minimal \\
\hline Total PV FCF explicit period & 2.160 .618 & 1.985 .209 \\
PV Terminal Value & 8.465 .877 & 4.975 .310 \\
Total Enterprise Value & 10.626 .495 & 6.960 .519 \\
Less debt & $(4.487 .486)$ & $(4.487 .486)$ \\
Equity Value & 6.139 .009 & 2.473 .033 \\
Numbers of Share & 237,38012 & 237,38012 \\
Price per share & 25.862 & 10.418 \\
\hline & Sumber: data diolah
\end{tabular}

Hasil perhitungan valuasi terhadap PT. TMJ, nilai saham perlembar pada komposisi maksimum adalah sebesar Rp.25.862,- /lembar saham atau 2,5 kali dari nilai saham saat ini. Sedangkan nilai pada komposisi minimum adalah sebesar Rp.10.418,-/lembar saham atau 1,0418 kali dari nilai saham saat ini.

Tabel 12. Laporan Penilaian Valuasi Perusahaan PT. JSM

\begin{tabular}{ccc}
\hline & Maksimal & Minimal \\
\hline Total PV FCF explicit period & 1.737 .468 & 1.601 .368 \\
PV Terminal Value & 6.307 .930 & 3.757 .031 \\
Total Enterprise Value & 8.045 .398 & 5.358 .399 \\
Less debt & $(3.997 .697)$ & $(3.997 .697)$ \\
Equity Value & 4.047 .701 & 1.360 .702 \\
Numbers of Share & 1.494 & 1.494 \\
Price per share & 2.709 & 911 \\
\hline
\end{tabular}

Sumber: data diolah 
Hasil perhitungan valuasi terhadap PT. JSM menunjukkan nilai saham per lembar pada komposisi maksimum adalah sebesar Rp.2.709,- /lembar saham atau 2,7 kali dari nilai saham saat ini. Sedangkan nilai pada komposisi minimum adalah sebesar Rp.911,- / lembar saham atau 0,9 kali dari nilai saham saat ini

\section{KESIMPULAN DAN SARAN}

Kesimpulan dari penelitian mengenai struktur modal optimal dan Valuasi PT. Trans Marga Jateng dan PT. Jasamarga Surabaya Mojokerto adalah sebagai berikut:

1. Secara umum melalui perhitungan rasio keuangan, kinerja keuangan dari PT. Trans Marga Jateng dan PT. Jasamarga Surabaya Mojokerto dari tahun 2015 sampai dengan tahun 2019 menunjukan kinerja yang cukup baik dilihat dari perhitungan:

a. Rasio profitabilitas menunjukkan bahwa kemampuan perusahaan untuk menghasilkan laba dengan aset atau sumber daya yang dimiliki cenderung fluktuatif dari tahun 2015 sampai dengan 2019 dikarenakan pengoperasian jalan tol ruas Semarang-Solo dan ruas SurabayaMojokerto yang masih parsial/bertahap dimana sebagian ruas beroperasi dan sebagian masih dalam masa konstruksi. Ruas tol Surabaya-Mojokerto baru beroperasi penuh pada tahun 2018 dan untuk ruas Semarang-Solo beroperasi penuh pada tahun 2019 sekaligus tersambung dengan ruas jalan tol trans jawa.

b. Strategi yang dapat digunakan oleh manajemen perusahaan untuk meningkatkan kinerja keuangan dalam pengembalian tingkat investasi adalah dengan meningkatkan pendapatan dan melakukan program efisiensi biaya operasi serta strategi restrukturisasi utang guna memperoleh biaya keuangan yang lebih murah.

c. Rasio likuiditas, kemampuan perusahaan untuk memenuhi kewajiban perusahaan jangka pendek dengan aset lancar yang dimiliki tumbuh secara positif

d. Rasio solvabilitas, kemampuan perusahaan untuk menyelesaikan kewajiban jangka panjang dengan jumlah aset yang dimiliki perlu menjadi perhatian tersendiri karena jumlah kewajiban jangka panjangnya cukup meningkat seiring dengan penyelesaian pembangunan jalan tol.

2. Komposisi struktur modal untuk mendapatkan nilai (value) yang optimal bagi PT. Trans Marga Jateng dan PT. Jasamarga Surabaya Mojokerto berkisar antara 60:40 sampai dengan 30:70 untuk komposisi utang dan equity.

3. Dari perhitungan Valuasi dari PT. Trans Marga Jateng (PT. TMJ) dan PT. Jasamarga Surabaya Mojokerto (PT. JSM) dengan menggunakan metode DCF (Discounted Cash Flow), nilai perusahaan PT. TMJ, dengan komposisi struktur modal 60:40 adalah senilai Rp.25.862,/lembar saham dan dengan komposisi modal 70:30 nilai saham PT. TMJ sebesar Rp.10.418,/lembar saham. Sedangkan untuk PT. JSM dengan komposisi struktur modal 60:40 adalah 
senilai Rp.2.709,- /lembar saham dan dengan komposisi modal 70:30 nilai saham PT. JSM sebesar Rp.911,- /lembar saham.

Saran yang dapat diberikan kepada manajemen perusahaan adalah:

1. Dalam menentukan struktur modal yang optimal, biaya modal sangat berpengaruh sehingga perusahaan perlu memperhatikan besarnya biaya modal. Besaran biaya modal disini adalah biaya modal rata-rata tertimbang (Weighted Average Cost of Capital). Manajemen perlu memperhatikan faktor-faktor yang mempengaruhi besaran biaya modal rata-rata tertimbang seperti tingkat suku bunga pinjaman, tarif pajak yang berlaku dan komposisi atas struktur modal yang akan digunakan. Karenanya manajemen harus mampu menentukan komposisi sumber pendanaan dan mendapatkan sumber pendanaan dengan biaya modal yang paling minimal seperti mampu mendapatkan sumber pendanaan dari utang dengan biaya bunga yang paling kompetitif dan penggunaan modal sendiri dengan memperhatikan tingkat suku bunga bebas risiko, tingkat suku buka premium dan kondisi pasar yang mempengaruhi nilai saham perusahaan.

2. Dengan memperhatikan struktur modal yang optimal, PT. Trans Marga Jateng dan PT. Jasamarga Surabaya Mojokerto dapat melakukan penurunan porsi debt dan meningkatkan porsi equity dengan beberapa strategi melalui:

a) Menerbitkan saham baru.

Dengan menerbitkan saham baru maka jumlah equity perusahaan bisa bertambah. Dengan bertambahnya equity perusahaan, maka porsi utang perusahaan bisa menurun. Uang yang didapatkan perusahaan dari penerbitan saham baru ini dapat digunakan untuk menjalankan proyek usaha lain ataupun untuk membayar utang perusahaan.

b) Menerbitkan convertible bond

Dengan menerbitkan convertible bond maka utang tersebut kemungkinan bisa dikonversikan menjadi kepemilikan saham di PT. Trans Marga Jateng dan PT. Jasamarga Surabaya Mojokerto. Perusahaan bisa mengkonversikan utang tersebut menjadi saham di perusahaan jika dirasakan keputusan tersebut adalah yang terbaik untuk perusahaan. 


\section{DAFTAR PUSTAKA}

Bambang Riyanto. (2010). Dasar-Dasar Pembelanjaan Perusahaan. Yogyakarta, BPFE,

Christiawan, Y.J., dan Tarigan J. (2007). Kepemilikan Manajerial: Kebijakan Hutang, Kinerja dan Nilai Perusahaan. Jurnal Akuntansi dan Keuangan. Universitas Kristen Petra. 9(1). PP 1-8

Damodaran, Aswath. (2012). Investment Valuation Tools and Techniques for Determining the Value of Any Asset. New Jersey: John Wiley \& Sons, Inc.

Detik.com (2019, 29 Oktober). Target Ambisius Jokowi, Panjang Tol RIdi 2024 Capai 5.200 km, diakses pada 13 Mei 2020 dari https://finance.detik.com/infrastruktur/d-4764139/target-ambisiusjokowi-panjang-tol-ri-di-2024-capai-5200-km

Djaja, Irwan. (2018). All About Corporate Valuation. Jakarta: Elex Media Komputindo

Hamidah, (2019). Manajemen Keuangan. Jakarta: Mitra Wacana Media

Hanafi, Mamduh dan Halim, Abdul, (2016). Analisis Laporan Keuangan. Yogyakarta: STIE YKPN.

Hery. (2016). Financial Ratio for Business. Jakarta. Grassindo.

Heru Prasetyo, Aris. (2011). Valuasi Perusahaan, Pedoman Untuk Praktisi dan Mahasiswa. Jakarta: PPM Manajemen

Kasmir. (2017). Analisis Laporan Keuangan. Rajawali Pers: Jakarta.

Munawir. (2007). Analisis Laporan Keuangan. Yogyakarta: Edisi Keempat, Liberty

Naibaho, Okthaleon. (2012). Analisis Struktur Modal Optimal PT. X. Jakarta: Universitas Indonesia.

Raharjaputra, Hendra S. (2011). Manajemen Keuangan dan Akuntansi. Jakarta: Salemba Empat

Subramanyam, KR dan Wild,John J. (2012). Analisis Laporan Keuangan. Jakarta: Salemba Empat 